\begin{tabular}{c|c|c|}
\cline { 3 - 3 } CRITICAL & $\begin{array}{l}\text { Western Ghats } \\
\text { PARTNERSHIP FUND }\end{array}$ \\
\cline { 3 - 4 } & Special Series \\
\hline
\end{tabular}

\title{
Rediscovery of the threatened Western Ghats endemic sisorid catfish Glyptothorax poonaensis (Teleostei: Siluriformes: Sisoridae)
}

\author{
Neelesh Dahanukar ${ }^{1}$, Manawa Diwekar ${ }^{2} \&$ Mandar Paingankar ${ }^{3}$ \\ 1,2 Indian Institute of Science Education and Research, Sai Trinity, Garware Circle, Pune, Maharashtra 411021, India \\ ${ }^{3}$ Department of Zoology, University of Pune, Ganeshkhind, Pune, Maharashtra 411007, India \\ Email: ${ }^{1}$ n.dahanukar@iiserpune.ac.in (corresponding author), ${ }^{2}$ manawa.d@iiserpune.ac.in, ${ }^{3}$ mandarpaingankar@gmail.com
}

Date of publication (online): 26 July 2011 Date of publication (print): 26 July 2011 ISSN 0974-7907 (online) | 0974-7893 (print)

Editor: Heok Hee Ng

\section{Manuscript details:}

Ms \# 02663

Received 30 December 2010

Final received 08 July 2011

Finally accepted 11 July 2011

Citation: Dahanukar, N., M. Diwekar \& M. Paingankar (2011). Rediscovery of the threatened Western Ghats endemic sisorid catfish Glyptothorax poonaensis (Teleostei: Siluriformes: Sisoridae). Journal of Threatened Taxa 3(7): 1885-1898.

Copyright: (c) Neelesh Dahanukar, Manawa Diwekar \& Mandar Paingankar 2011. Creative Commons Attribution 3.0 Unported License. JoTT allows unrestricted use of this article in any medium for non-profit purposes, reproduction and distribution by providing adequate credit to the authors and the source of publication.

Author Detail: see end of this article

Author Contribution: ND and MP designed the research and performed morphometry; MD performed molecular biology work; ND and MP analyzed the data and wrote the paper.

Acknowledgements: We are thankful to Prof L.S. Shashidhara, Prof. Milind Watve and Dr. Sanjay Molur for continuous support and encouragement. We are thankful to Dr. R.M. Sharma, Officer-in-charge, and Shrikant Jadhav, Zoological Survey of India, Western Regional Centre, Akurdi, Pune, for encouragement and helpful discussion. We thank two anonymous referees for comments on an earlier draft of the manuscript. The CEPF-funded freshwater assessment of the Western Ghats encouraged us to publish this work. We duly acknowledge the help from CEPF for publication of this article.

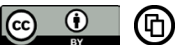

OPEN ACCESS | FREE DOWNLOAD
Abstract: Glyptothorax poonaensis Hora is an endemic sisorid catfish of the Western Ghats of India known only from its type locality in Mula-Mutha River, a tributary of Bhima River, at Pune. This fish has not been recorded from its type locality for more than 70 years and it was thought to be extinct. Here we report a recently discovered population of G. poonaensis from Indrayani River, a tributary of Bhima River. Based on 11 specimens, we have redescribed this species along with some comments on its taxonomy, length-weight relationship, feeding and breeding habits. We also performed molecular phylogeny of the fish by sequencing three mitochondrial genes encoding $16 \mathrm{~S}$ ribosomal DNA, cytochrome $b$ and cytochrome oxidase subunit I. Molecular analysis suggests that $G$. poonaensis is nested within a lineage of Glyptothorax species from northern and northeastern India and China. Further, our analysis reveals that southern Indian species of Glyptothorax do not form a monophyletic group. Molecular dating of divergence times indicates that $G$. poonaensis diverged from other northern Indian species 1.9 to 2.5 million years ago. Current knowledge suggests that the species could be found in two river basins with total extent of around $6100 \mathrm{~km}^{2}$; however, the species is already suspected to be locally extinct from half of its known extent of occurrence. Furthermore, the habitat of the species may be threatened by increasing pollution, deforestation leading to siltation, halting of flow by damming, sandmining and introduced fish species. In the light of biodiversity conservation, especially in an important biodiversity hotspot like Western Ghats, such rare and endemic species needs prioritization.

Keywords: Conservation, Glyptothorax poonaensis, molecular phylogeny, northern Western Ghats.

\section{INTRODUCTION}

The Western Ghats of India harbor a rich diversity of freshwater fish with many species endemic to this region (Shaji et al. 2000; Dahanukar et al. 2004). However, a major part of this diversity is threatened by various anthropogenic activities (Dahanukar et al. 2004), and unless serious efforts are taken to conserve natural resources, it is possible that rare and endemic species in this biodiversity hotspot may go extinct in the near future. This is especially true for stenotopic fish species like the

This article forms part of a special series on the Western Ghats of India, disseminating the results of work supported by the Critical Ecosystem Partnership Fund (CEPF), a joint initiative of l'Agence Française de Développement, Conservation International, the Global Environment Facility, the Government of Japan, the MacArthur Foundation and the World Bank. A fundamental goal of CEPF is to ensure civil society is engaged in biodiversity conservation. Implementation of the CEPF investment program in the Western Ghats is led and coordinated by the Ashoka Trust for Research in Ecology and the Environment (ATREE). 
ones in the genus Glyptothorax, which prefer clear hill streams with rapid currents. Globally, Glyptothorax is represented by more than 70 species (Anganthoibi \& Vishwanath 2010). In the Western Ghats, Glyptothorax is currently represented by 10 species (Gopi 2010), namely G. anamalaiensis Silas, G. annandalei Hora, G. davissinghi Manimekalan \& Das, G. housei Herre, G. kudremukhensis Gopi, G. lonah (Sykes), G. madraspatanum (Day), G. malabarensis Gopi, G. poonaensis Hora, and G. trewavasae Hora. Out of these species, $G$. poonaensis is considered to be extinct from its type locality (Kharat et al. 2003).

Hora (1938) described G. poonaensis as a subspecies of $G$. conirostre, from the Mula-Mutha River, a tributary of Bhima River in the northern Western Ghats, India. The description was based on five specimens, one of which was collected by A.G.L. Fraser during 1936-1937 from Kharadigaon area of Mula-Mutha River (Hora 1938; Fraser 1942). Since then at least three independent studies were carried out on the freshwater fish fauna of Mula-Mutha Rivers by Tonapi \& Mulherkar (1963), Wagh \& Ghate (2003; this work was actually carried out during 1992-1995) and Kharat et al. (2003) and this species has never been encountered. Studies on other nearby rivers, namely Pavana River (Chandanshive et al. 2007) and Indrayani River (Yazdani \& Mahabal 1976), which are tributaries of Mula-Mutha and Bhima rivers respectively, did not record this species either. In an extensive survey of Krishna River system, Jayaram (1995) did not record this species but noted that it had been recently recorded by Ghate et al. (1992). However, Ghate et al. (1992) did not base their record on material they collected, but on records in earlier literature. Glyptothorax poonaensis is also mentioned in the checklist of fish from Pune District by Tilak \& Tiwari (1976) but it remains unclear whether this record is based on actual collection or the existing literature. Similarly, Yadav (2003) recorded this species from the collection of Western Regional Station, Zoological Survey of India, Pune, during 1960-1995, without mentioning collection localities or dates of collection. As a result, there are no reliable records of $G$. poonaensis since its original description in 1938. This is the reason Kharat et al. (2003) considered G. poonaensis to be possibly extinct in the Mula-Mutha River after a detailed survey of the river drainage.

In a resent survey of Indrayani River, also a tributary of Bhima River (and very close to the MulaMutha River of Pune; approximately $18 \mathrm{~km}$ by land but around $120 \mathrm{~km}$ river stretch from the type locality of the fish) we discovered a population of $G$. poonaensis. In this paper we redescribe the species with further details on its morphomety, molecular phylogeny, current distribution, length-weight relationship, feeding habits, breeding habit and threats to the species. This data will be helpful while designing and implementing conservation strategies.

\section{METHODS}

\section{Study area and specimen collection}

The Indrayani River is a tributary of Bhima River, which is itself a major tributary of the Krishna River system. In our study on the fish diversity of Indrayani River, specimens of Glyptothorax were collected at Markal $\left(18.671^{\circ} \mathrm{N}, \& 73.981^{\circ} \mathrm{E}\right)$ from June to August 2010 from the local fishermen. The specimens were preserved in $4 \%$ formaldehyde and were identified based on available literature (Hora 1938; Silas 1951; Talwar \& Jhingran 1991; Jayaram 2010). Four specimens from our study are deposited in the collection of Wildlife Information Liaison Development, Coimbatore under the accession numbers WILD-11-PIS-004, WILD-11PIS-005, WILD-11-PIS-006 and WILD-11-PIS-018. Three specimens from our collection are deposited in the Zoological Survey of India, Western Regional Centre, Akurdi, Pune under the accession numbers ZSI Pune $\mathrm{P} / 2431, \mathrm{P} / 2432$ and $\mathrm{P} / 2433$.

\section{Biological and morphological data collection and analysis}

Morphometric and meristic data were collected following Vishwanath \& Linthoingambi (2005), Ng \& Kottelat (2008) and Jayaram (2010). Wherever there was discrepancy in the definition of a morphometric character, for example body depth at anus $(\mathrm{Ng} \&$ Kottelat 2008) versus body depth at dorsal origin (Jayaram 2010), we took both the measurements and recorded them appropriately. In all 40 morphometric characters and four meristic characters were considered. Morphometry was performed using dial calipers with a least count of $0.0254 \mathrm{~mm}$. We also extracted morphometric data for G. poonaensis, G. conirostre, $G$. lonah and G. trewavasae from Hora (1938) for 
comparison. To avoid personal measurement biases while comparing Hora's (1938) data and ours we performed cluster analysis based on the mean values of size adjusted morphometric data. We calculated Euclidian distances and we used Ward's method of clustering. Weight of each individual was measured on an electronic weighing balance with a least count of $0.01 \mathrm{~g}$. We plotted log-log plot of length and weight of the fish to determine the exponent of the length-weight relationship given by the equation $\mathrm{W}=\mathrm{a} \mathrm{L}^{\mathrm{b}}$, where ' $\mathrm{W}$ ' is the weight, ' $\mathrm{a}$ ' is the normalization constant, ' $\mathrm{L}$ ' is the length and ' $b$ ' is the scaling exponent. The null hypothesis that ' $b=3$ ' was tested by comparing the $95 \%$ confidence interval of calculated value of 'b' (Quinn II \& Deriso 1999, pp.131). We dissected three specimens in our collection to extract their gut contents and analyzed their feeding habits.

\section{DNA isolation and molecular phylogeny}

Muscle tissues were harvested from two fresh specimens (WILD-11-PIS-018 and ZSI Pune P/2431) and were preserved in absolute ethanol. The tissue was digested at $50^{\circ} \mathrm{C}$ for two hours using the STE buffer $(0.1 \mathrm{M} \mathrm{NaCl}, 0.05 \mathrm{M}$ Tris-HCl, 0.01M EDTA, $1 \% \mathrm{SDS})$ with $15 \mu \mathrm{l}$ proteinase $\mathrm{K}(20 \mathrm{mg} / \mathrm{ml})$ per $500 \mu \mathrm{l}$ of STE buffer. DNA was extracted using conventional phenol-chloroform method and re-suspended in nuclease free water. Polymerase chain reaction was performed to amplify three fragments of mitochondrial genes namely cytochrome b (cyt-b), cytochrome oxidase subunit I (cox1) and 16S ribosomal DNA (16S rDNA). Primers used for the amplification are given in the Table 1. PCR was performed in a $50 \mu 1$ reaction volume containing $5 \mu \mathrm{l}$ of template DNA ( $200 \mathrm{ng}), 5 \mu \mathrm{l}$ of $10 \mathrm{x}$ reaction buffer $(100 \mathrm{mM}$ Tris $\mathrm{pH} 9.0,500 \mathrm{mM}$ $\mathrm{KCl}, 15 \mathrm{mM} \mathrm{MgCl}_{2}, 0.1 \%$ gelatin), $2 \mu 1$ of $25 \mathrm{mM}$ $\mathrm{MgCl}_{2}, 2 \mu \mathrm{l}$ of $10 \mathrm{mM}$ dNTPs, $1 \mu \mathrm{l}$ of each primer, $1 \mu \mathrm{l}$ taq polymerase and $33 \mu 1$ distilled water. The genes were amplified using gene-specific primers. For $16 \mathrm{~S}$ rDNA thermal profile was $5 \mathrm{~min}$ at $95^{\circ} \mathrm{C}$, and 40 cycles of 30 seconds at $94^{\circ} \mathrm{C}, 30$ seconds at $61^{\circ} \mathrm{C}$ and $2 \mathrm{~min}$ at $72^{\circ} \mathrm{C}$ followed by extension of $10 \mathrm{~min}$ at $72^{\circ} \mathrm{C}$. For cyt-b and cox 1 thermal profile was $5 \mathrm{~min}$ at $95^{\circ} \mathrm{C}$, and 40 cycles of 30 seconds at $94^{\circ} \mathrm{C}, 30$ seconds at $51^{\circ} \mathrm{C}$ and $2 \mathrm{~min}$ at $72^{\circ} \mathrm{C}$, followed by extension of $10 \mathrm{~min}$ at $72^{\circ} \mathrm{C}$. Amplified DNA fragments were purified using the 'Promega Wizard Gel and PCR clean up' system and sequenced. The purified PCR products were sequenced using $\mathrm{ABI}$ prism 3730 sequencer (Applied Biosystems, USA) and big dye terminator sequencing kit (ABI Prism, USA). Sequences were analyzed by BLAST tool (Altschul et al. 1990). These sequences have been deposited in Genbank.

We retrieved additional sequences of other species of Glyptothorax from NCBI GenBank (http://www. ncbi.nlm.nih.gov/). We used Gagata cenia and Bagarius yarrelli as out-groups following Peng et al. (2006). All the sequences used for the analysis, along with their GenBank accession number, are given in Table 2. Our total data matrix encompasses fragments of three mitochondrial genes namely $16 \mathrm{~S}$ rDNA, cyt-b and cox1 with a total sequence length of $2120 \mathrm{bp}$ after alignment. Sequences were aligned using ClustalW (Thompson et al. 1994). Phylogenetic and molecular evolutionary analyses were conducted using MEGA version 5 (Tamura et al. 2011). Best fit model for nucleotide substitution was selected based on minimum Akaike Information Criterion (AIC) value (Posada \& Crandall 2001). We constructed phylogenetic trees based on maximum parsimony, minimum evolution, neighbour joining and maximum likelihood. Reliability of the phylogenetic tree was estimated using bootstrap values run for 1000 iterations. Based on the calibration points available

Table 1. Primer sequences used in this study

\begin{tabular}{|c|c|c|c|c|c|}
\hline Gene amplified & Primer & Sequence $\left(5^{\prime} \rightarrow 3^{\prime}\right)$ & $\mathrm{Tm}$ & $\begin{array}{l}\text { Approximate size of } \\
\text { amplification (bp) }\end{array}$ & Reference \\
\hline \multirow{2}{*}{ cyt-b } & L14724 (F) & GACTTGAAAAACCACCGTTG & 50 & \multirow{2}{*}{1118} & \multirow{2}{*}{ Chen et al. (2007) } \\
\hline & H15915 (R) & CTCCGATCTCCGGATTACAAGAC & 57 & & \\
\hline \multirow{2}{*}{$\operatorname{cox} 1$} & FishF1 & TCAACCAACCACAAAGACATTGGCAC & 58 & \multirow{2}{*}{655} & \multirow{2}{*}{$\begin{array}{l}\text { Sharina \& Kartavtsev } \\
\text { (2010) }\end{array}$} \\
\hline & FishR1 & TAGACTTCTGGGTGGCCAAAGAATCA & 58 & & \\
\hline \multirow{2}{*}{$16 \mathrm{~S}$ rDNA } & $16 \mathrm{Sar}-\mathrm{F}$ & CGCCTGTTTATCAAAAACAT & 46 & \multirow{2}{*}{573} & \multirow{2}{*}{ Ivanova et al. (2007) } \\
\hline & $16 \mathrm{Sbr}-\mathrm{R}$ & CCGGTCTGAACTCAGATCACGT & 57 & & \\
\hline
\end{tabular}


Table 2. GenBank details of gene sequences used for phylogenetic analysis

\begin{tabular}{|l|l|c|c|l|}
\hline \multirow{2}{*}{ Species } & \multicolumn{3}{|c|}{ GenBank accession numbers } & \multirow{2}{*}{ Voucher specimen number } \\
\cline { 2 - 5 } & $\mathbf{1 6 S}$ rDNA & Cytochrome b & Cytochrome oxidase-1 & \\
\hline Glyptothorax brevipinnis & FJ357193 & FJ208934 & FJ208927 & NBFGR:GB1 \\
\hline Glyptothorax cavia & AY445906 & AF477830* & DQ514343 & $\begin{array}{l}\text { IHB200106243 (for 16S rDNA) } \\
\text { UMMZ 247440 (for Co-1) }\end{array}$ \\
\hline Glyptothorax dakpathari & FJ357197 & EU637440 & EU637832 & NBFGR:GP3 \\
\hline Glyptothorax davissinghi & FJ357212 & FJ423582 & FJ347795 & NBFGR:GD8318G \\
\hline Glyptothorax fokiensis & AY574359 & AF416884* & DQ514346 & $\begin{array}{l}\text { IHB3811 (for 16S rDNA) } \\
\text { UMMZ 245065 (for Co-1) }\end{array}$ \\
\hline Glyptothorax garhwali & FJ357186 & EU637428 & EU637803 & NBFGR:GG1 \\
\hline Glyptothorax granulus & FJ357181 & FJ349168 & FJ347865 & NBFGR:GR8413X \\
\hline Glyptothorax ngapang & FJ357173 & FJ349120 & FJ347817 & NBFGR:GN8412K \\
\hline Glyptothorax poonaensis & JN092395 & JN092396 & JN092397 & WILD-11-PIS-018 \\
\hline Glyptothorax poonaensis & HQ833462 & HQ833463 & HQ833464 & ZSI, Pune, P/2431 \\
\hline Glyptothorax sinensis & AY574357 & AY601764 & DQ514360 & $\begin{array}{l}\text { IHB0305147 (for 16S rDNA) } \\
\text { IHB0305147 (for Cyt-b) } \\
\text { UMMZ 246438 (for Co-1) }\end{array}$ \\
\hline Glyptothorax ventrolineatus & FJ357203 & FJ349177 & FJ347797 & NBFGR:GV8417A \\
\hline Gagata cenia & AY445905 & AF499599* & DQ846700 & $\begin{array}{l}\text { IHB9907005 (for 16S rDNA) } \\
\text { UMMZ 247439 (for Co-1) }\end{array}$ \\
\hline
\end{tabular}

*Voucher specimen not specified

on the molecular dating of Gagata cenia and Bagarius yarrelli (Peng et al. 2006) we performed molecular dating using maximum likelyhood analysis based on cyt-b gene sequence. A molecular clock test was performed to find out whether the substitution rates were uniform (Tamura et al. 2011).

\section{RESULTS AND DISCUSSION}

In spite of several extensive surveys in the MulaMutha River and other rivers in the vicinity of Pune (Tonapi \& Mulherkar 1963; Yazdani \& Mahabal 1976; Kharat et al. 2003; Wagh \& Ghate 2003; Chandanshive et al. 2007), G. poonaensis has not been recorded after its description by Hora (1938). The only other records of the fish by Tilak \& Tiwari (1976) and Yadav (2003) could be based only on existing literature (see Introduction). As a result our report of $G$. poonaensis is the first verifiable record since its original description.

\section{Taxonomic comments}

We compared the specimens in our collection with the original description in Hora (1938) and confirmed their conspecificity. We further confirmed the identity of $G$. poonaensis by comparing our morphological data with the data for G. poonaensis, G. conirostre, G. lonah and G. trewavasae from Hora (1938). Size adjusted morphometric data from Hora (1938) and our specimens (Table 3) agree closely, further verifying their conspecificity. The only disagreement between our data and that in Hora (1938) is the length of caudal peduncle. Our measurements (19.3-22.7\% SL) are higher than those reported by Hora (16.6-17.5\% SL), however, we cannot comment on the reasons behind this difference because of the small sample sizes in both cases. The dendrogram (Fig. 1) based on the morphometrical comparisons (Table 3) suggests that

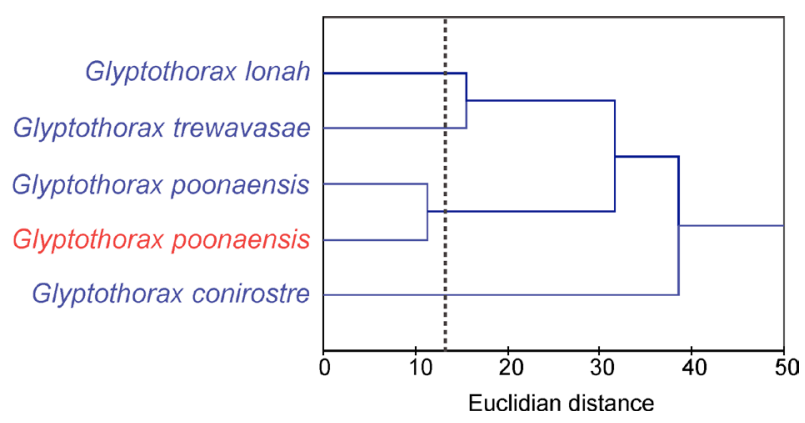

Figure 1. Comparison of morphometric data of present collection with Hora's (1938) data. Dendrogram is plotted using Euclidian distances and Ward's method. (Species names shown in blue are based on Hora's (1938) data, while red corresponds to present study). Dashed line is the significance line. 
Table 3. Comparison among the morphometry of Glyptothorax given by Hora (1938) and present study. All characters are expressed as average of percentage of standard length with their standard deviations in the parenthesis.

\begin{tabular}{|c|c|c|c|c|c|}
\hline \multirow{2}{*}{$\begin{array}{l}\text { Characters } \% \text { of standard } \\
\text { length }\end{array}$} & \multicolumn{4}{|c|}{ Data from Hora (1938) } & \multirow{2}{*}{$\begin{array}{l}\text { Present study } \\
\text { G. poonaensis }\end{array}$} \\
\hline & G. poonaensis & G. conirostre & G. Ionah & G. trewavasae & \\
\hline Length of head & $23.6(0.36)$ & $22.7(0.73)$ & $23.8(0.66)$ & $25.7(0.68)$ & $23.8(1.40)$ \\
\hline Width of head & $20.2(1.44)$ & $16.7(0.22)$ & $20.1(0.33)$ & $20.8(0.43)$ & $19.1(1.32)$ \\
\hline Height of head & $13.0(1.03)$ & $12.1(0.05)$ & $14.2(0.52)$ & $12.8(1.16)$ & $13.3(1.08)$ \\
\hline Length of snout & $11.5(1.08)$ & $11.6(0.52)$ & $11.8(0.86)$ & $13.5(1.51)$ & $12.3(0.36)$ \\
\hline Inter-orbital width & $6.4(0.32)$ & $5.4(0.97)$ & $8.0(0.67)$ & $7.4(0.52)$ & $7.1(0.59)$ \\
\hline Depth of body & $15.5(1.83)$ & $15.1(1.17)$ & $18.2(1.04)$ & $15.5(1.42)$ & $17.1(1.12)$ \\
\hline Height of dorsal fin & $16.8(0.97)$ & $19.9(0.36)$ & $18.5(1.41)$ & $19.4(2.11)$ & $16.8(0.86)$ \\
\hline Length of pectoral fin & $21.6(1.30)$ & $24.2(0.10)$ & $23.5(0.57)$ & $22.1(3.37)$ & $20.6(1.40)$ \\
\hline Length of ventral fin & $15.8(1.48)$ & $17.8(1.39)$ & $19.0(0.58)$ & $16.9(0.97)$ & $14.8(0.72)$ \\
\hline Longest ray of anal fin & $14.2(1.91)$ & $18.9(0.26)$ & $18.5(1.40)$ & $17.5(2.68)$ & $15.8(1.28)$ \\
\hline Length of dorsal spine & $12.5(0.16)$ & $14.2(0.86)$ & $13.1(0.95)$ & $13.4(0.86)$ & $12.4(0.63)$ \\
\hline Length of caudal peduncle & $17.1(0.46)$ & $21.3(1.25)$ & $17.6(1.06)$ & $17.8(0.83)$ & $20.7(0.88)$ \\
\hline Least height of caudal peduncle & $8.2(0.33)$ & $9.1(0.02)$ & $11.1(0.74)$ & $8.6(1.52)$ & $8.5(1.35)$ \\
\hline
\end{tabular}

not only our specimens are similar to G. poonaensis sensu stricto but $G$. poonaensis is significantly different from its closely related northern Indian species $G$. conirostre and other species, namely $G$. lonah and $G$. trewavasae, described from the northern Western Ghats of India.

Glyptothorax poonaensis was originally described as a valid subspecies of $G$. conirostre. Menon (1999) elevated its status to the species level without giving any rationale and the trend was followed by Thomson \& Page (2006). Jayaram $(2009,2010)$ however still considers the species as a valid subspecies of $G$. conirostre, while, Ferraris (2007) has considered the species as species inquirendae owing to the fact that the species has either been treated as valid or as a synonym of $G$. conirostre. Our analysis based on the data available on $G$. conirostre in Hora (1938) and comparison of our material of $G$. poonaesis with the original description of $G$. conirostre given by Steindachner (1867) indicates that $G$. poonaensis is a valid species markedly distinct from $G$. conirostre. Comparison of standardized characters given in (Table 3 ) suggests that $G$. conirostre is different from $G$. poonaensis in the head width and lengths of different fins. As compared to Glyptothorax conirostre, $G$. poonensis has lesser height of dorsal fin (15.1-18.1\% SL vs. 19.6-20.1\% SL), length of pectoral fin (18.6$22.8 \%$ SL vs. $24.2-24.3 \%$ SL), length of ventral fin (13.7-15.8 \% SL vs. 16.8-18.8 \% SL), length of longest anal fin ray (13.8-18.4 \% SL vs. 18.7-19.1 $\% \mathrm{SL})$ and length of dorsal spine (11.1-13.4\% SL vs. $13.6-14.8 \% \mathrm{SL})$. However, as compared to $G$. conirostre, G. poonaensis has larger head width (17.0$21.2 \%$ SL vs. $16.5-16.8 \% \mathrm{SL}$ ) and inter orbital width (6.2-8.3\% SL vs. $4.7-6.0 \%$ SL). Jayaram (2009) has separated G. poonaensis from G. conirostre based on having broader head, shorter dorsal fin and posterior insertion of pelvic fins. We therefore suggest that $G$. poonaensis should be considered as a valid species distinct from G. conirostre.

Glyptothorax poonaensis can be differentiated from nine other species of Glyptothorax known from the Western Ghats using a combination of characters (Hora 1938; Silas 1951; Talwar \& Jhingran 1991; Jayaram 2009; Gopi 2010). Glyptothorax poonaensis differs from other species known from the Western Ghats, namely $G$. anamalaiensis, $G$. annandalei, G. davissinghi, G. kudremukhensis, G. lonah, G. trewavasae and G. madraspatanum, in having smooth skin as oppose to tuberculated or granulated skins in all other species. Apart from the difference in the skin character, G. poonaensis can be easily differentiated from $G$. anamalaiensis in lacking (vs. having) three broad white bands on the body. Glyptothorax annandalei and $G$. davissinghi can be separated from $G$ poonaensis in having plaited (vs. smooth) ventral surfaces of the paired fins. Glyptothorax poonaensis can be differentiated from G. annandalei, 
G. davissinghi, G. lonah, G. trewavasae and G. malabarensis. Glyptothorax poonaensis differs from madraspatanum in having poorly developed (vs. well developed) adhesive apparatus. Here, poorly developed adhesive thoracic apparatus can be defined as consisting of ridges of skin with only 16 prominent striae and only anterior striae well defined while posterior striae indistinct, as oppose to well developed adhesive thoracic apparatus with more then 20 striae and both anterior and posterior striae distinctly visible. Other Glyptothorax species found in the Western Ghats, which have smooth skin, are G. housei and G.

$G$. housei by a poorly developed (vs. well developed) adhesive thoracic apparatus, smooth (vs. plaited) ventral surfaces of the paired fins, shorter (vs. longer) maxillary and nasal barbels and dorsal fin origin nearer to adipose fin than to tip of snout (vs. nearer to tip of snout than adipose fin base). Glyptothorax poonaensis differs from $G$. malabarensis in having the thoracic adhesive apparatus poorly developed and longer than broad (vs. moderately developed, pentagonal in shape and as long as broad).
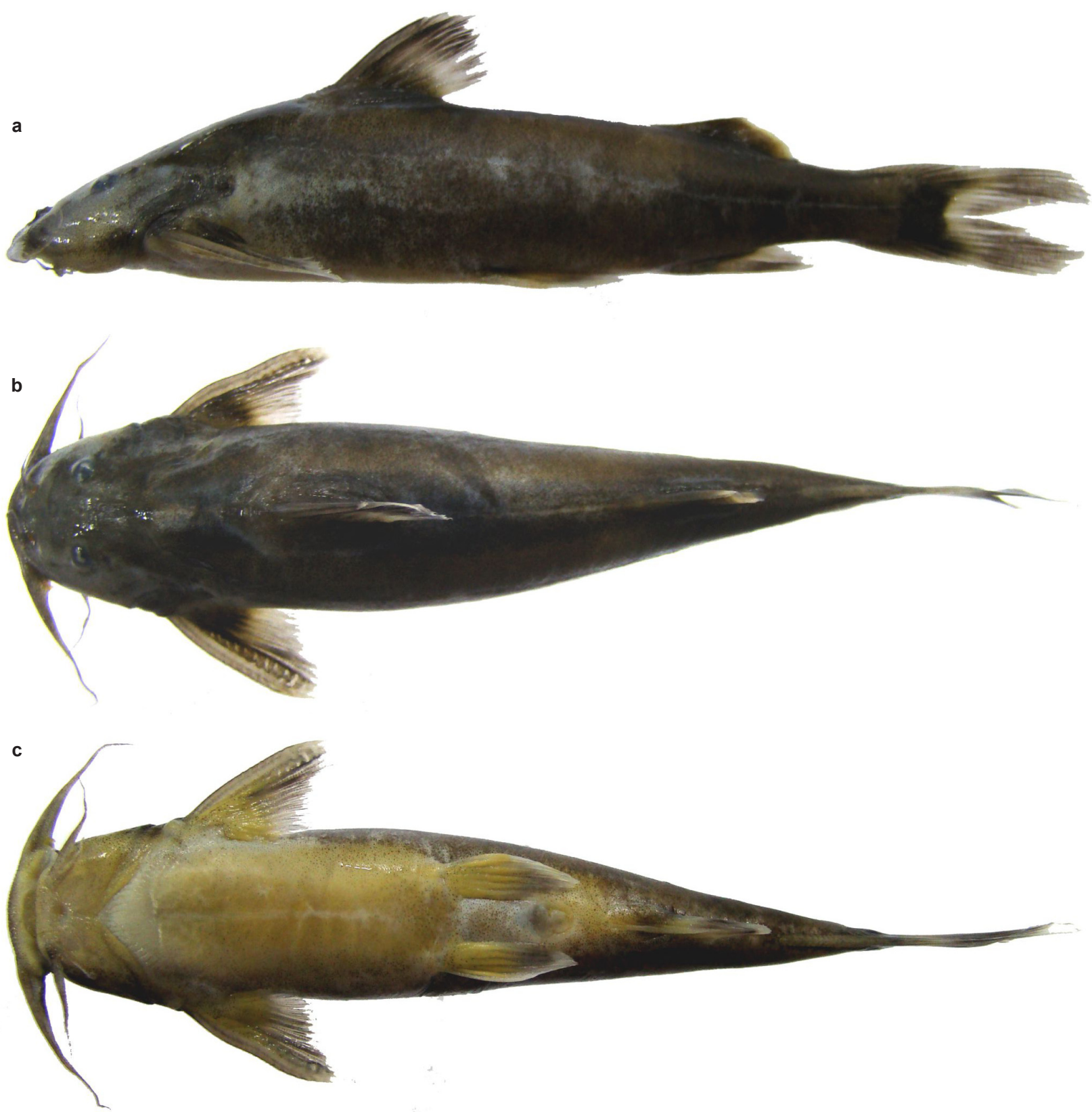

Image 1. Details of Glyptothorax poonaensis (WILD-11-PIS-004). a - Lateral; b - dorsal; c - ventral view. 

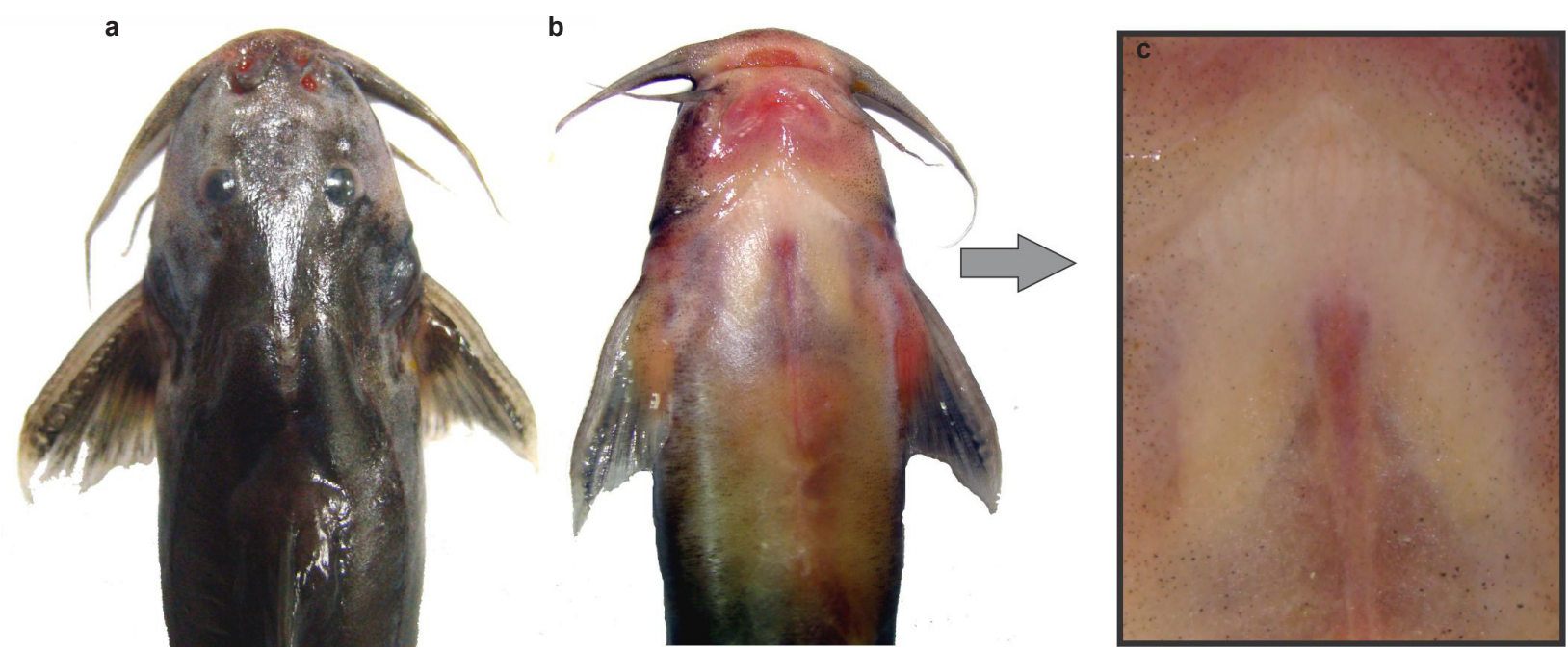

Image 2. Details of the head and adhesive thoracic apparatus of Glyptothorax poonaensis (ZSI Pune P/2431) a - Dorsal profile of head; $b$ - ventral profile of head; c - details of adhesive thoracic apparatus.
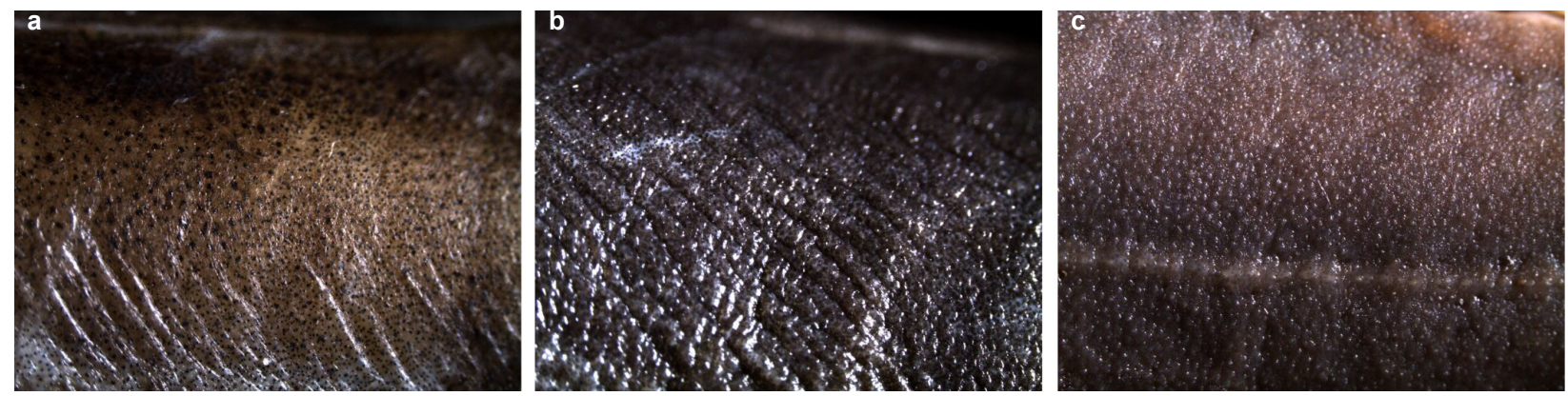

Image 3. (a) Smooth (WILD-11-PIS-004), and (b) wrinkled (WILD-11-PIS-018) skin of Glyptothorax poonaensis and its comparison with (c) tuberculated skin of $G$. Ionah (unregistered specimen collected from Koyna River).

\section{Redescription of Glyptothorax poonaensis}

Detailed morphometry of $G$. poonaensis is given in Table 4 and details of the body structure, head structure and details of skin are presented in Images 1,2 and 3 respectively. The redescription is based on the freshly collected specimens as indicated in Table 4. The specimens deposited in WILD match exactly in morphology the types (4 specimens bearing the registration number F12126/1) deposited at the Zoological Survey of India, Kolkata.

Head depressed, body subcylindrical. Dorsal profile rises evenly from tip of snout to origin of dorsal fin then slopes gently ventrally from origin of dorsal fin to end of caudal peduncle. Ventral profile flat from snout tip to anal fin base, then slopes gently dorsally from anal fin base to end of caudal peduncle. Anus and urogenital openings located at vertical through middle of adpressed pelvic fin. Skin smooth on body and head but could be wrinkled in some specimens occurring either as a preservation artifact or molting (Image 3). Lateral line complete, mid-lateral in position.

Head depressed and broad. Snout prominent. Anterior and posterior nares large and separated only by base of nasal barbels. Gill opening broad, extending from immediately ventral to post-temporal to isthmus. Bony elements of dorsal surface of head covered with thick, smooth skin. Occipital process does not reach base of dorsal fin. On either side of supraoccipital process, supracleithrum forms two finger like projections separated by large interspace as shown by Hora (1938: fig. 1c). Eye ovoid, located entirely on dorsal half of head, its horizontal axis longest, its diameter 9.8-13.5\% HL.

Barbels four pairs, maxillary barbel long and slender extending to middle of pectoral fin base. Nasal barbels slender, barely reaching eye. Inner mandibular barbel origin close to midline extending up to gill opening on ventral surface. Outer mandibular barbel 
Table 4. Raw data of morphometric $(\mathrm{mm})$ and meristic characters of Glyptothorax poonaensis

\begin{tabular}{|c|c|c|c|c|c|c|c|c|c|c|c|}
\hline Character & GP1 $1^{a, b}$ & GP2 a, c & GP3 & GP4 ${ }^{c}$ & GP5 b & GP6 & GP7 ${ }^{c}$ & GP8 & GP9 b & GP10 b & GP11 \\
\hline Total length & 128.14 & 112.98 & 111.13 & 110.08 & 108.38 & 144.55 & 124.46 & 111.30 & 108.97 & 109.27 & 104.60 \\
\hline Standard length & 105.56 & 91.95 & 90.96 & 91.67 & 89.71 & 120.50 & 102.24 & 94.23 & 89.46 & 90.55 & 87.12 \\
\hline Length of caudal & 24.38 & 19.56 & 19.05 & 19.38 & 19.76 & 24.87 & 21.95 & 19.00 & 21.46 & 19.81 & 17.68 \\
\hline Pedorsal length & 37.34 & 31.12 & 31.50 & 32.84 & 32.69 & 40.51 & 35.94 & 35.97 & 31.80 & 31.88 & 30.45 \\
\hline Pre anal length & 63.27 & 54.79 & 53.34 & 52.98 & 54.97 & 70.99 & 61.75 & 56.87 & 52.73 & 55.85 & 52.91 \\
\hline Prepelvic length & 53.01 & 44.60 & 43.38 & 43.33 & 44.04 & 57.56 & 49.66 & 48.90 & 43.36 & 46.28 & 42.34 \\
\hline Pre pectoral length & 18.75 & 17.27 & 16.64 & 17.40 & 16.81 & 20.88 & 17.50 & 16.89 & 16.51 & 17.07 & 16.71 \\
\hline Length of head & 25.96 & 19.00 & 20.70 & 22.20 & 22.58 & 28.50 & 22.61 & 23.04 & 21.89 & 22.61 & 21.59 \\
\hline Depth of head at occiput & 11.56 & 11.38 & 11.56 & 11.99 & 12.40 & 17.15 & 14.10 & 12.27 & 13.18 & 13.08 & 11.56 \\
\hline Depth of head at eye & 9.65 & 8.81 & 8.48 & 9.19 & 9.45 & 12.78 & 10.36 & 8.59 & 9.35 & 8.76 & 8.46 \\
\hline Width of head & 17.96 & 15.80 & 16.64 & 16.64 & 18.14 & 25.53 & 20.02 & 18.92 & 17.17 & 17.37 & 17.53 \\
\hline Width of head near nares & 11.13 & 10.16 & 11.38 & 10.77 & 12.19 & 15.60 & 11.99 & 10.80 & 10.72 & 10.16 & 9.86 \\
\hline Length of snout & 12.58 & 11.45 & 11.36 & 11.42 & 11.26 & 13.82 & 12.3 & 11.64 & 11.24 & 11.33 & 11.05 \\
\hline Eye diameter & 2.69 & 2.57 & 2.54 & 2.54 & 2.57 & 2.79 & 2.67 & 2.41 & 2.59 & 2.92 & 2.69 \\
\hline Interorbital width & 6.63 & 6.48 & 6.81 & 6.35 & 5.59 & 8.59 & 7.01 & 7.11 & 7.44 & 6.60 & 5.92 \\
\hline Internarial space & 2.67 & 2.57 & 3.00 & 3.05 & 2.90 & 4.17 & 3.51 & 3.43 & 3.71 & 3.81 & 3.18 \\
\hline Gape width & 10.34 & 8.76 & 8.69 & 8.53 & 9.63 & 11.07 & 8.74 & 9.91 & 8.86 & 9.27 & 8.38 \\
\hline Nasal barbel length & 8.92 & 6.48 & 6.76 & 6.58 & 7.21 & 9.14 & 9.14 & 6.96 & 7.95 & 8.08 & 8.20 \\
\hline Maxillary barbel length & 23.57 & 19.69 & 21.62 & 18.39 & 20.47 & 30.78 & 27.05 & 22.28 & 21.34 & 19.10 & 18.67 \\
\hline Innermandibular barbel length & 10.26 & 9.63 & 7.34 & 7.62 & 7.92 & 9.02 & 7.24 & 8.36 & 8.79 & 7.75 & 8.38 \\
\hline Outer mandibular barbel length & 15.57 & 13.67 & 11.89 & 12.50 & 12.75 & 15.93 & 13.16 & 12.70 & 13.34 & 11.53 & 12.01 \\
\hline Depth of body at dorsal origin & 18.14 & 15.80 & 16.51 & 14.27 & 16.74 & 22.38 & 18.26 & 15.72 & 15.04 & 14.68 & 13.41 \\
\hline Depth of body at anus & 15.24 & 13.82 & 14.12 & 13.08 & 14.43 & 21.03 & 17.22 & 13.13 & 13.67 & 13.26 & 12.83 \\
\hline Width of body at dorsal origin & 16.94 & 15.54 & 14.78 & 14.76 & 17.30 & 19.46 & 16.05 & 17.53 & 15.37 & 16.38 & 14.88 \\
\hline Width of body at anal origin & 11.23 & 12.24 & 10.72 & 11.07 & 12.32 & 14.83 & 12.45 & 10.97 & 11.51 & 11.13 & 10.21 \\
\hline Height of dorsal fin & 17.58 & 15.11 & 13.69 & 15.29 & 15.77 & 21.03 & 18.47 & 14.86 & 15.24 & 14.86 & 15.04 \\
\hline Length of dorsal fin base & 12.24 & 11.05 & 11.48 & 11.02 & 10.95 & 13.26 & 10.21 & 10.54 & 11.25 & 10.39 & 10.41 \\
\hline Dorsal spine length & 11.76 & 11.68 & 10.87 & 11.33 & 11.40 & 15.88 & 12.70 & 11.18 & 11.00 & 11.53 & 11.68 \\
\hline Length of adipose fin base & 10.97 & 10.36 & 10.36 & 9.68 & 9.53 & 13.54 & 9.93 & 9.19 & 10.54 & 9.65 & 10.67 \\
\hline Post adipose distance & 20.98 & 19.38 & 17.83 & 17.91 & 17.40 & 23.11 & 21.21 & 18.82 & 17.78 & 17.58 & 16.89 \\
\hline Dorsal to adipose distance & 25.02 & 21.84 & 21.39 & 22.73 & 22.15 & 32.64 & 29.46 & 23.37 & 21.26 & 24.26 & 20.88 \\
\hline Length of pectoral fin & 21.46 & 19.46 & 16.89 & 17.58 & 19.33 & 27.13 & 23.32 & 17.65 & 18.69 & 18.85 & 17.73 \\
\hline Length of pectoral spine & 15.09 & 15.11 & 12.45 & 14.61 & 14.35 & 22.86 & 20.83 & 14.35 & 13.54 & 13.77 & 14.20 \\
\hline Length of ventral fin & 16.66 & 13.79 & 12.47 & 13.16 & 13.16 & 18.62 & 16.13 & 12.95 & 13.41 & 13.46 & 12.45 \\
\hline Length of anal fin base & 11.40 & 9.91 & 8.33 & 9.65 & 7.90 & 12.50 & 11.73 & 10.62 & 10.03 & 11.28 & 9.83 \\
\hline Length of largest anal fin ray & 16.66 & 15.11 & 13.41 & 14.02 & 13.61 & 16.64 & 16.99 & 14.10 & 15.47 & 16.64 & 13.54 \\
\hline Length of caudal peduncle & 22.00 & 18.97 & 19.33 & 18.42 & 18.67 & 27.31 & 21.44 & 18.21 & 18.75 & 17.91 & 17.53 \\
\hline Least height of caudal peduncle & 8.33 & 7.11 & 7.01 & 7.44 & 6.88 & 13.34 & 11.53 & 7.16 & 7.11 & 7.16 & 7.75 \\
\hline Length of adhesive apparatus & 14.12 & 13.67 & 13.56 & 12.65 & 12.60 & 16.97 & 15.72 & 11.94 & 15.06 & 14.10 & 12.90 \\
\hline Width of adhesive apparatus & 13.34 & 12.70 & 11.99 & 10.36 & 11.46 & 11.56 & 12.34 & 10.52 & 11.94 & 10.67 & 10.72 \\
\hline Dorsal fin rays & 16 & 16 & 16 & 16 & 16 & 15 & 16 & 16 & 16 & 16 & 16 \\
\hline Pectoral fin rays & 17 & 18 & 18 & 18 & 19 & 19 & 19 & 18 & 18 & 18 & 18 \\
\hline Ventral fin rays & i 5 & i 5 & i 5 & i 5 & i 5 & i 5 & i 5 & i 5 & i 5 & i 5 & i 5 \\
\hline Anal fin rays & ii 8 & ii 8 & ii 8 & ii 8 & ii 8 & ii 8 & ii 8 & ii 8 & ii 9 & ii 9 & ii 9 \\
\hline
\end{tabular}

a - specimens used for DNA isolation; ${ }^{\mathrm{b}}$ - deposited at Wildlife Information Liaison Development, Coimbatore, Accession numbers: GP1 = WILD-11PIS-018, GP5 = WILD-11-PIS-004, GP9 = WILD-11-PIS-005, GP10 = WILD-11-PIS-006; ${ }^{\circ}-$ deposited at Zoological Survey of India, Western Regional Centre, Pune, Accession numbers: GP2 $=$ P/2431, GP4 $=$ P/2432, GP7 $=$ P/2433 
originating posteriolateral of inner mandibular barbel extending to origin of pectoral fin. Mouth inferior, premaxillary tooth band partially exposed when mouth is closed. Oral teeth small and villiform in irregular rows, premaxillary teeth in single broad semilunate band. Dentary teeth in two narrow crescentic bands separated at midline.

Dorsal fin located above anterior third of body with I,5 $(\mathrm{N}=1)$ or I,6 $(\mathrm{N}=10)$ rays; fin margin convex; spine short and gently curved. Adipose fin with anterior margin concave. Caudal fin strongly forked with lower lobes slightly longer than upper lobes. Procurrent rays symmetrical, extending slightly anterior on fin base. Anal fin base ventral to adipose fin origin. Anal fin with concave anterior margin and straight posterior margin with ii,8 $(\mathrm{N}=8)$ or ii,9 $(\mathrm{N}=3)$ rays. Pelvic fin origin slightly behind the posterior end of dorsal fin base. Pelvic fin with slightly convex margin and i,5 rays. Tip of adpressed fin not reaching anal fin origin but covers anus and urogenital area. Pectoral fin with I,7 $(\mathrm{N}=1)$ or I,8 $(\mathrm{N}=7)$ or I,9 $(\mathrm{N}=3)$ fin rays posterior fin margin slightly convex. Anterior spine margin smooth, posterior margin with 17-21 serrations.

Thoracic adhesive apparatus present, weakly developed, forming a narrow band and somewhat $\mathrm{V}$ shaped appearance (Image 2c), with median depression present on posterior half and extending from isthmus to level of middle of pectoral fin. Median ridges oriented longitudinally, ridges uninterrupted.

In $4 \%$ formaldehyde dorsal and lateral surfaces of head grayish with yellow tinge. A dark gray patch on the dorsal profile extending from occipital process to posterior base of adipose fin. Ventral surface yellow to pale yellow. Dorsal fin gray with white band in middle, pectoral, ventral and anal fins with yellow base and gray tips. Caudal fin with black or dark gray base followed by gray tips. Head and body studded with randomly-distributed minute black dots. On the lateral surfaces of the body gray with yellow tinge sometimes give rise to brownish coloration.

\section{Molecular phylogeny}

ModelTest in MEGA 5 (Tamura et al. 2011) suggested that General Time Reversible + Gamma + Proportion Invariant $(\mathrm{GTR}+\mathrm{G}+\mathrm{I})$ model was the best fit model for nucleotide substitution for our data and thus it was applied to generate phylogenetic hypothesis. The results for phylogenetic analysis based on maximum likelihood, maximum parsimony, minimum evolution and neighbor joining are shown in Fig. 2. The phylogeny based on a combined analysis of all three data partitions (16S rDNA, cyt-b and cox1) suggests that $G$. poonaensis is nested within a clade consisting of species from the northern part of the Indian subcontinent and China (Fig. 2). Interestingly, G. poonaensis and G. davissinghi, both Western Ghats species, were separated by a larger distance suggesting that southern Indian Glyptothorax do not form a monophyletic group.

Molecular dating of divergence times between $G$. poonaensis and other northern Indian species suggests that $G$. poonaensis diverged from other northern Indian species between 1.9 to 2.5 million years ago (Fig. 3). We used only cyt-b gene for molecular dating because (Peng et al. 2006) have considered cyt-b gene for their analysis and we are using same reference for the calibaration. Further, our total data matrix consisting of $16 \mathrm{~S}$ rDNA, cyt-b and cox1 had non uniform substitution rates. Also, we could not use $16 \mathrm{~S}$ rDNA and cox 1 genes individually as their sequence length was small for statistical analysis. However, for cyt-b the sequence length was adequate for analysis and the null hypothesis of equal evolutionary rate throughout the tree was not rejected $(p=0.2065)$ making the molecular dating more reliable.

\section{Distribution and population status}

The collection locality of one paratype of $G$. poonaensis is Kharadigaon $\left(18.545^{\circ} \mathrm{N} \& 73.949^{\circ} \mathrm{E}\right)$, Pune (Hora 1938; Fraser 1942), while the type locality (where three paratypes were also collected) is more vague, being merely given as "near Poona [=Pune]". We collected the species from the Village Markal $\left(18.671^{\circ} \mathrm{N}\right.$ $\& 73.981^{\circ} \mathrm{E}$ ) situated on the right bank of Indrayani River, Pune. The two collection sites are numbered 1 and 2 respectively in Fig. 4 and the associated river basins are highlighted in blue. The total area drained by the two river basins is $6105.4 \mathrm{~km}^{2}$. However, it is suspected that the species could be locally extinct from the Mula-Mutha River (Kharat et al. 2003), indicating that the current extent of occurrence (IUCN 2001) of this fish could be reduced by at least half. We lack estimates of the population size of this species, but it is possible that it is relatively rare. This is based on the fact that in the extensive survey of Mula-Mutha River by Fraser (1942) only one specimen was collected. 

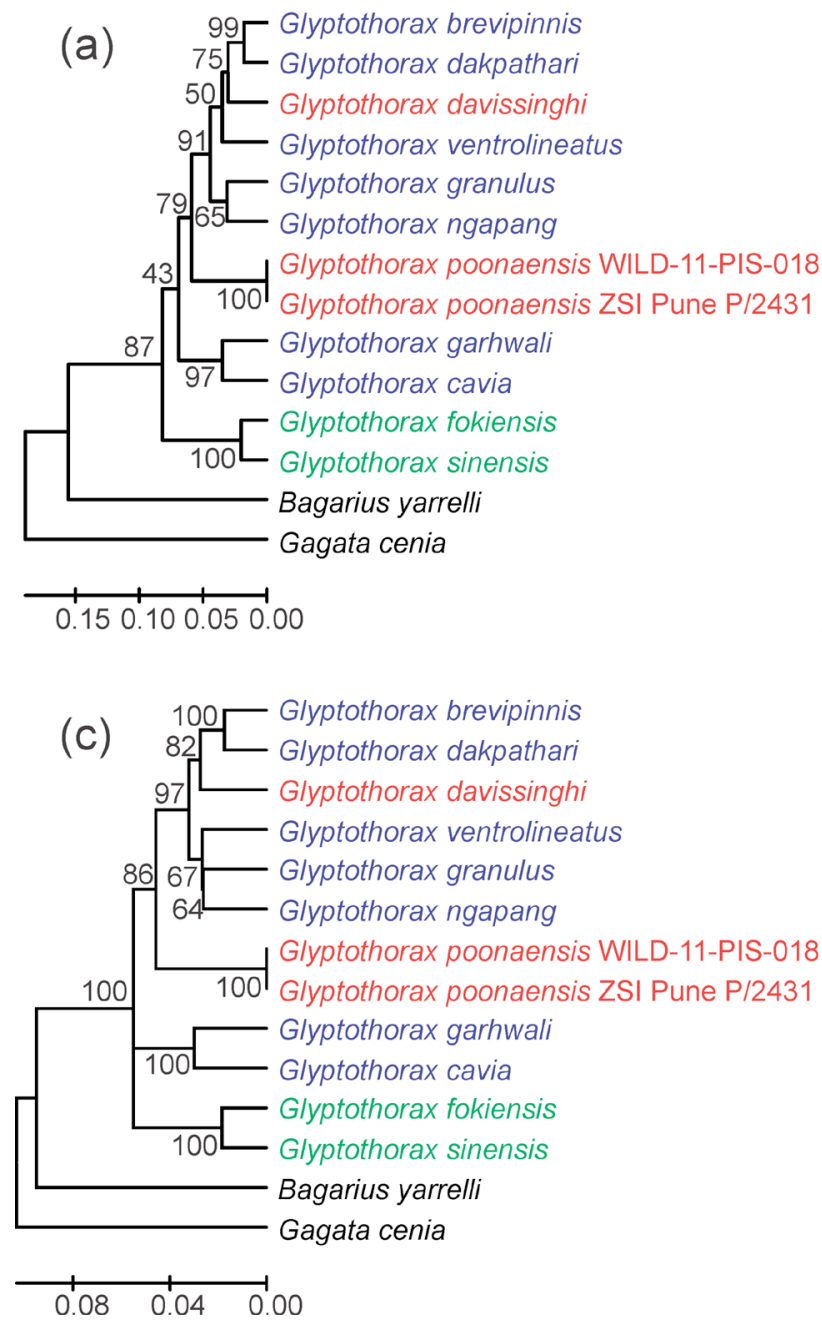
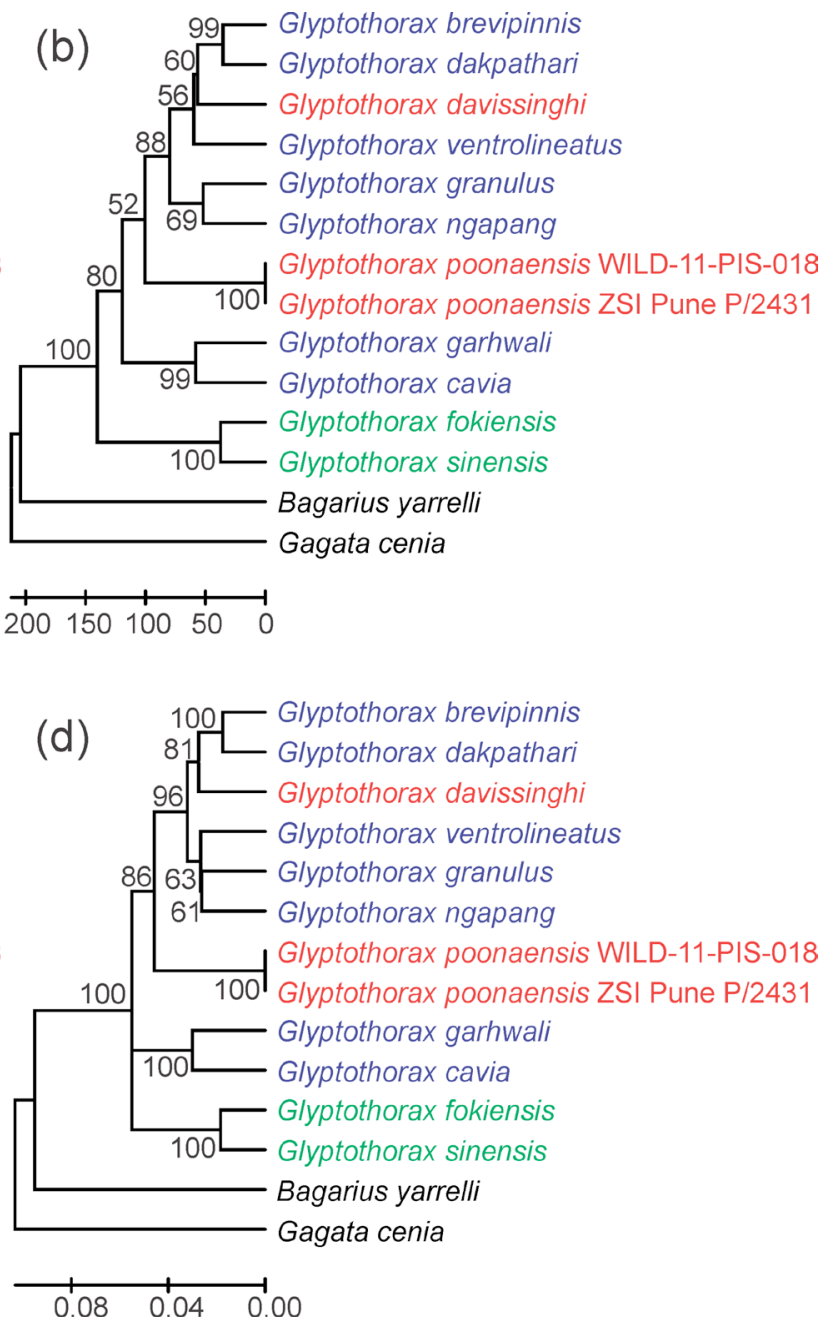

Figure 2. Phylogenetic position of Glyptothorax poonaensis. Phylogenetic tree constructed using (a) maximum likelihood, (b) maximum parsimony, (c) minimum evolution and (d) neighbor joining analysis using 2120 base pairs of partial 165 rDNA, cyt-b and cox1 gene sequences. Values at each node are Bootstrap values for 1000 iterations. Gagata cenia and Bagarius yarrelli are used as out groups. Species names in blue indicate northern Indian and northeastern Indian species, species names in green indicate Chinese species and species name in red are Western Ghats species.

Further, previous study on Indrayani River (Yazdani \& Mahabal 1976) failed to collect this species. Our discussions with the fishermen revealed that this species, locally called as Patthar-chatu, is found only during summer and early rainy season when the water level is low and even during this period the fish is very rare. However, since directed fishing efforts for this particular species are not done, we do not have exact estimates for the species abundance.

\section{Biology}

The length weight relation of unsexed G. poonaensis can be described by the equation $\mathrm{W}=0.0087 L^{3.2436}$ (Fig. $\left.5, \mathrm{R}^{2}=0.933, \mathrm{p}<0.001\right)$. Since, the $95 \%$ confidence interval of scaling exponent was in the range 2.5882 -
3.8989 , the null hypothesis, stated as the found value of the exponent is not significantly different from the predicted value of 3 by isometry, could not be rejected. Thus the fish grows isometrically. Gut content of three specimens of $G$. poonaensis suggested that the fish feeds on benthic macroinvertebrates such as freshwater prawns (Image 4A), maxillopod crustacean (Branchiura) (Image 4B) and Odonata nymph (Image $4 C)$. Our collection of gravid females suggests that this species probably breeds during June to August (the monsoon season). Similar observations are also made on other species of Glyptothorax (Dobriyal \& Singh 1993; Nath 1994; Kaul 1994). Based on the fact that Glyptothorax are known to migrate downstream for breeding (Kaul 1994), we suspect that Markal could 


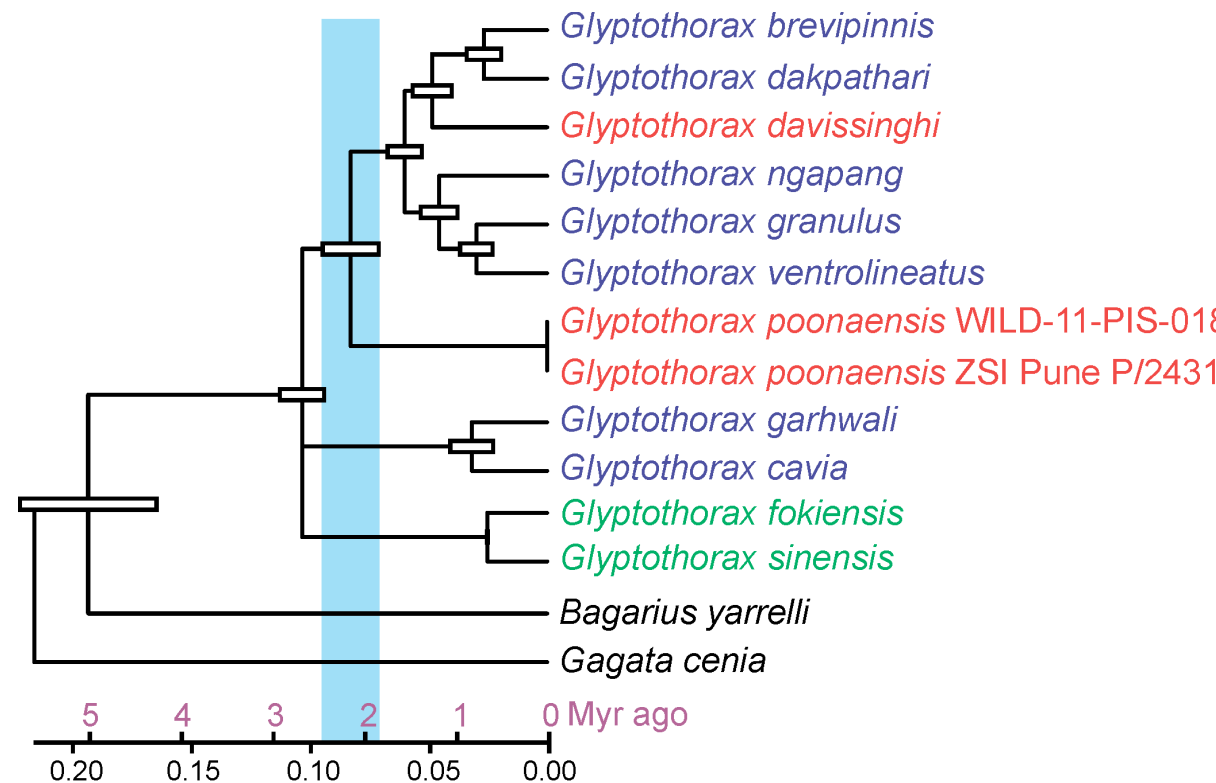

Figure 3. Molecular dating of Glyptothorax poonaensis based on maximum likelyhood analysis of cyt-b gene and the molecular calibrations available for divergence time between Gagata cenia and Bagarius yarrelli and between Bagarius yarrelli and Glyptothorax fokiensis (Peng et al. 2006). White bars on each node represent the $95 \%$ confidence interval of divergence time. Color code for species names as per Figure 2.

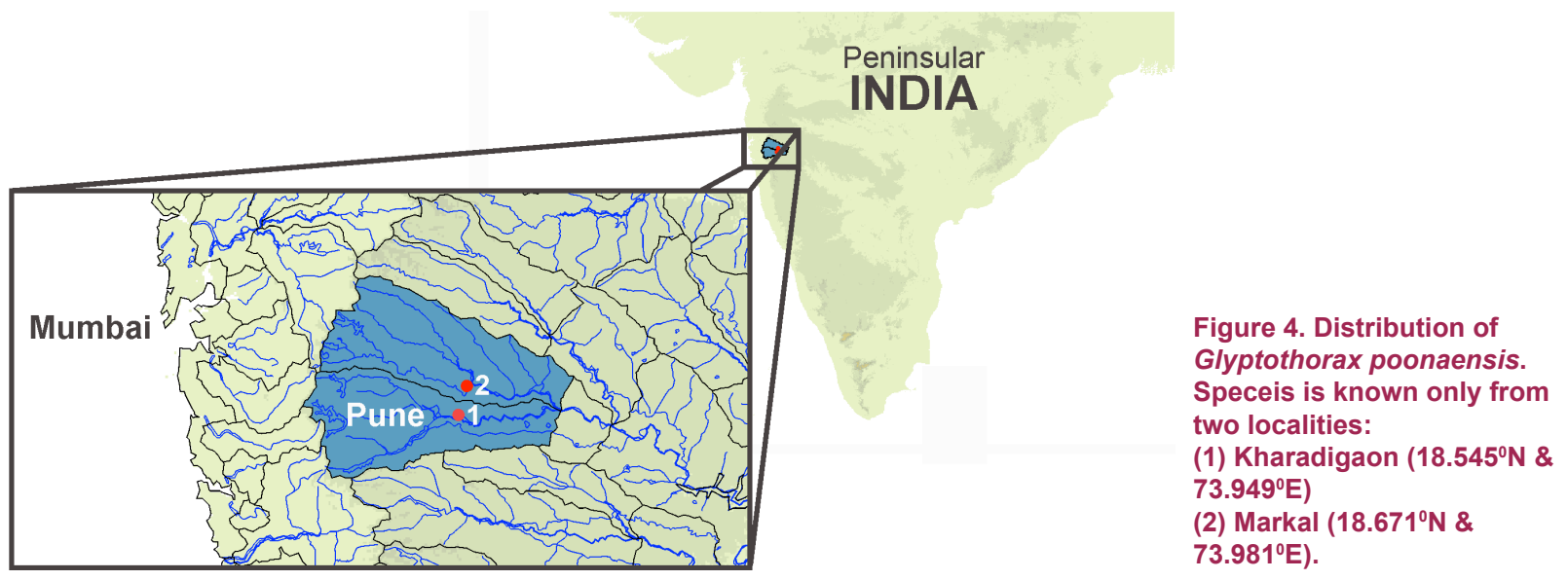

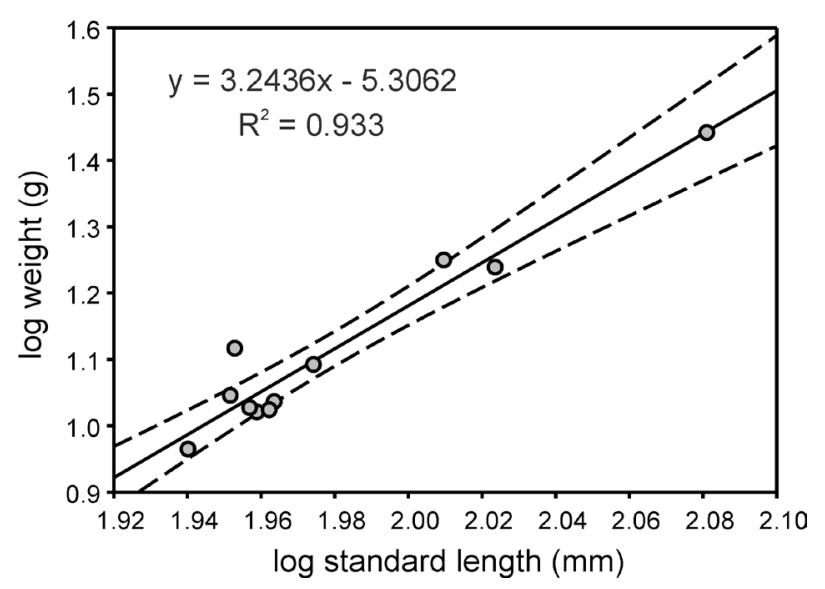

Figure 5. Length weight relationship of Glyptothorax poonaensis. Dashed lines indicate $95 \%$ confidence interval. be the breeding ground for G. poonaensis. This is because Markal is located on the main river and there are no hill streams in its immediate vicinity. Further, according to the local fishermen, the species is found in Markal area only during June to August, which is thought to be the breeding period of the fish.

\section{Threats and conservation measures}

There are several threats to G. poonaensis in its known range. Important threats to hill stream species like G. poonaensis include alteration of hydrological regimes because of damming, increasing pollution, deforestation leading to siltation, and introduced fish species. Dams cut the flow of water and lessen the speed of water creating semi-lacustrine conditions. These conditions may be highly disliked by hill 

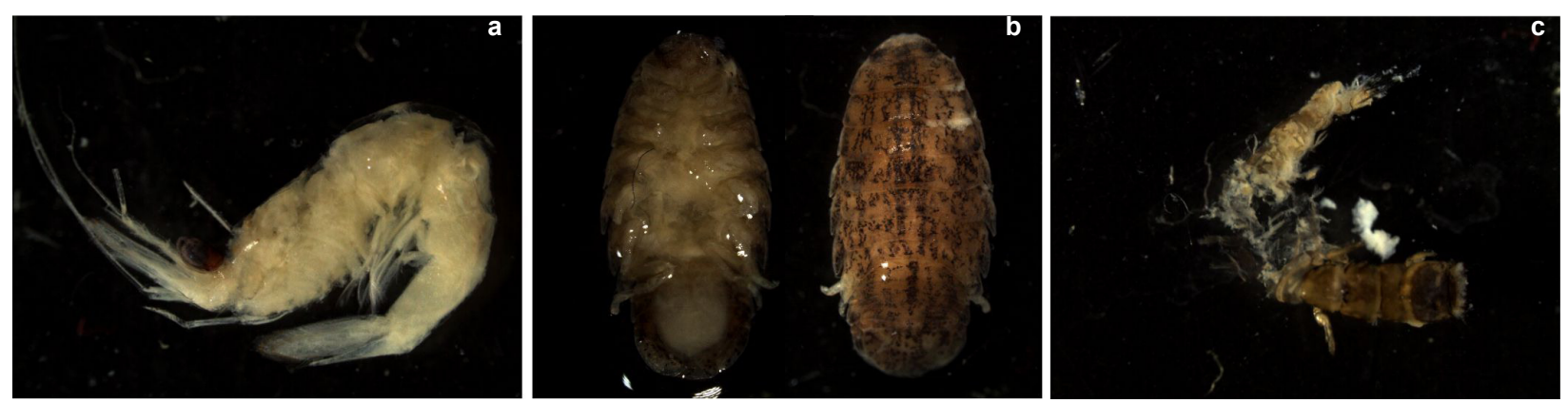

Image 4. Food items from the gut of Glyptothorax poonaensis - (a) freshwater prawn, (b) maxillopod crustacean (Branchiura) and (c) Odonata nymph.

stream fishes like Glyptothorax, which are specialized fro living in torrent streams (Hora 1930). Also, Glyptothorax utilize gravel bed areas for spawning which are lost in rivers immediately below the dams (Kaul 1994; Nath 1994). Further, impeded water flow (both upstream and downstream of the dam) can lead to eutrophication and the creation of oxygen-poor habitats. As species of genus Glyptothorax require large amounts of oxygen in water (Hora 1930) such habitat alterations are unsuitable for the species. Similar habitat alterations can also result from urbanization leading to organic pollution in rivers. Such changes in the rivers near the study area and their possible effects on the fish fauna are already documented (Kharat et al. 2003; Wagh \& Ghate 2003). As stated before, we suspect that Indrayani River at Markal could be the breeding ground for G. poonaensis as Glyptothorax species are known to migrate downstream for breeding (Kaul 1994). If this is true then pollution in this area, which is an ongoing threat, is of major concern. An ongoing threat in terms of deforestation, leading to siltation, can also affect the breeding grounds of the fish. Recently we also observed sandmining on large scale at Markal (Image 5), which is likely to affect the habitat of $G$. poonaensis.

Another major threat to the species could be the presence of introduced exotic fish. Introduced exotic fishes have been documented as major threats to fishes in the peninsular India (Kharat et al. 2003; Daniels 2006; Raghavan et al. 2008; Knight 2010). Kharat et al. (2003) have argued that introduced fish like Oreochromis mossambica, Poecilia reticulata, Gambusia affinis, Heteropneustes fossilis, etc. in Mula-Mutha River, are threatening the existence of many native fishes and might have caused even local extinction of some species including G. poonaensis.
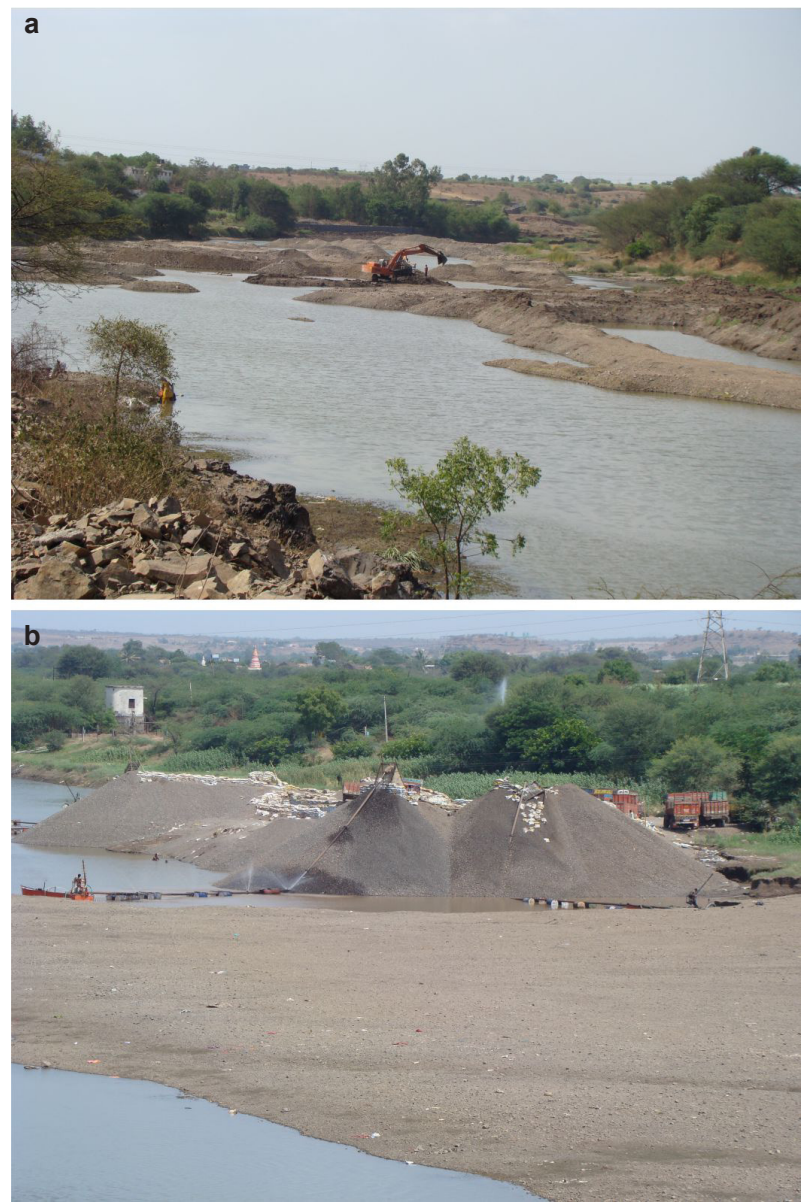

Image 5. Sandmining in Indrayani River at (a) Markal and (b) downstream of Markal is a potential threat to $G$. poonaensis habitat.

Even in Indrayani River at Markal we recorded alien species such as Oreochromis mossambica and Clarias gariepinus. Although direct evidence is lacking we suspect that at least Clarias gariepinus is a potential threat to the current population of G. poonaensis as it is a voracious predator (Krishnakumar et al. 2011). Restricted distribution of the speceis, decline in the 
extent of occurance, ongoing threats to the habitats and possible threats to the speceis justifies the IUCN Red list threat catagory of this species as Endangered under the criteria B2ab(i,ii,iii,iv) as assessed by Dahanukar (2010).

The potential breeding grounds of the fish at Markal and the upstreams of Indrayani River, especially hill streams in the adjoining hilly areas need protection. Halting of siltation by re-plantations and avoidance of pollution could be helpful in saving the breeding grounds. Management of the introduced fishes, especially Clarias gariepinus, by controlled eradication of escaped stock and increasing public awareness for avoiding further introductions (Sato et al. 2010), could also be helpful.

\section{REFERENCES}

Anganthoibi, N. \& W. Vishwanath (2010). Two new species of Glyptothorax from the Koladyne basin, Mizoram, India (Teleostei: Sisoridae). Ichthyological Explorations of the Freshwaters 21(4): 323-330

Altschul, S.F., W. Gish, W. Miller, E.W. Myers \& D.J. Lipman (1990). Basic local alignment search tool. Journal of Molecular Biology 215(3): 403-410.

Chandanshive, E.N., S.M. Kamble \& B.E. Yadav (2007). Fish fauna of Pavana river of Pune, Maharashtra. Zoos Print Journal 22(5): 2693-2694.

Chen, X.L., T.Y. Chiang, H.D. Lin, H.S. Zheng, K.T. Shao, Q. Zhang \& K.C. Hsu (2007). Mitochondrial DNA phylogeography of Glyptothorax fokiensis and Glyptothorax hainanensis in Asia. Journal of Fish Biology 70: 75-93.

Dahanukar, N. (2010). Glyptothorax poonaensis. In: IUCN 2011. IUCN Red List of Threatened Species. Version 2011.1. <www.iucnredlist.org>. Downloaded on 13 July 2011.

Dahanukar, N., R. Raut \& A. Bhat (2004). Distribution, endemism and threat status of freshwater fishes in the Western Ghats of India. Journal of Biogeography 31: 123 136.

Daniels, R.J.R. (2006). Introduced fishes: a potential threat to the native freshwater fishes of peninsular India. Journal of the Bombay Natural History Society 103(2-3): 346-348.

Dobriyal, A.K. \& H.R. Singh (1993). Reproductive biology of a hill stream catfish, Glyptothorax madraspatanum (Day), from the Garhwal, Central Himalaya, India. Aquaculture Research 24(6): 699-706.

Ferraris, C.J. Jr. (2007). Checklist of catfishes, recent and fossil (Osteichthyes: Siluriformes), and catalogue of siluriform primary types. Zootaxa 1418: 1-628.

Fraser, A.G.L. (1942). Fish of Poona. Part I. Journal of the Bombay Natural History Society 43(1): 79-91.
Ghate, H.V., G.K. Wagh \& S.L. Lokhande (1992). Fish fauna of the rivers Mula and Mutha, Pune, pp.105-115. In: Procedings of First National Symposium on Environmental Hydraulics, Central Water and Power Research Station, Pune.

Gopi, K.C. (2010). Glyptothorax malabarensis, a new catfish (Teleostei: Sisoridae) from the Western Ghats of Kerala, India. Zootaxa 2528: 53-60.

Hora, S.L. (1930). Ecology, bionomics and evolution of torrential fauna, with special reference to the organs of attachment. Philosophical Transactions of the Royal Society of London, Series B, 218: 171-282.

Hora, S.L. (1938). Notes on fishes in the Indian Museum. XXXVIII. On the systematic position of Bagrus lonah Sykes, with descriptions of and remarks on other Glyptosternoid fishes from the Deccan. Records of the Indian Museum 40(4): 363-375.

IUCN (2001). IUCN Red List Categories and Criteria: Version 3.1. IUCN Species Survival Commission. IUCN, Gland, Switzerland and Cambridge, UK, ii+30pp.

Ivanova, N.V., T.S. Zemlak, R.H. Hanner \& P.N. Hebert (2007). Universal primer cocktails for fish DNA barcoding. Molecular Ecology Notes 7(4): 544-548.

Jayaram, K.C. (1995). The Krishna river System: A Bioresources Study. Occasional Paper No. 160. Records of Zoological Society of India, 167pp.

Jayaram, K.C. (2009). Catfishes of India. Narendra Publishing House, New Delhi, 383pp.

Jayaram, K.C. (2010). The Freshwater Fishes of the Indian Region. Second Edition. Narendra Publishing House, Delhi, 616pp.

Kaul, B.L. (1994). Comparative fecundity of some Kashmir teleosts, pp.71-78. In: Nath, S. (ed.). Recent Advances in Fish Ecology, Limnology and Eco-conservation, volume 3, Daya Publishing House, Delhi.

Kharat, S., N. Dahanukar, R. Raut \& M. Mahabaleshwarkar (2003). Long-term changes in freshwater fish species composition in northern Western Ghats, Pune District. Current Science 84(6): 816-820.

Knight, J.D.M. (2010). Invasive ornamental fish: a potential threat to aquatic biodiversity in peninsular India. Journal of Threatened Taxa 2(2): 700-704.

Krishnakumar, K., A. Ali, B. Pereira \& R. Raghavan (2011). Unregulated aquaculture and invasive alien species: a case study of the African Catfish Clarias gariepinus in Vembanad Lake (Ramsar Wetland), Kerala, India. Journal of Threatened Taxa 3(5): 1737-1744.

Menon, A.G.K. (1999). Check List - Fresh Water Fishes of India. Occasional Paper No. 175. Records of the Zoological Survey of India, Kolkata, 366pp.

Nath, S. (1994). Studies on bioecology of fishes of Jammu Province (Jammu and Kashmir State) India, Part III. Spawning ecology, pp.79-82. In: Nath, S. (ed.). Recent Advances in Fish Ecology, Limnology and Eco-conservation. Volume 3. Daya Publishing House, Delhi.

Ng, H.H. \& M. Kottelat (2008). Glyptothorax rugimentum, a 
new species of catfish from Myanmar and Western Thiland (Teleostei: Sisoridae). The Raffles Bulletin of Zoology 56(1): 129-134.

Peng, Z., S.Y.W. Ho, Y. Zhang \& S. He (2006). Uplift of the Tibetan plateau: Evidence from divergence times of glyptosternoid catfishes. Molecular Phylogenetics and Evolution 39: 568-572.

Posada, D. \& K.A. Crandall (2001). Selecting the best-fit model of nucleotide substitution. Systems Biology 50(4): 580-601.

Quinn II, T.J. \& R.B. Deriso (1999). Quantitative Fish Dynamics. Qxford University Press, New York, 542pp.

Raghavan, R., G. Prasad, P.H. Anvar-Ali \& B. Pereira (2008). Exotic fish species in a global biodiversity hotspot: observations from river Chalakudy, part of Western Ghats, Kerala, India. Biological Invasions 10(1): 37-40.

Sato, M., Y. Kawaguchi, J. Nakajima, T. Mukai, Y. Shimatani \& N. Onikura (2010). A review of research on introduced freshwater fishes: new prospectives, the need for research, and management implications. Landscape Ecology and Engineering 6: 99-108.

Shaji, C.P., P.S. Easa \& A. Gopalakrishnan (2000). Freshwater fish diversity of Western Ghats, pp. 35-35. In: Ponniah, A.G. \& A. Gopalakrishnan (eds.). Endemic Fish Diversity of Western Ghats. NBFGR-NATP publication, National Bureau of Fish Genetic Resources, Lucknow, India, 347pp.

Sharina, S.N. \& Yu. P. Kartavtsev (2010). Phylogenetic and taxonomic analysis of flatfish species (Teleostei, Pleuronectiformes) Inferred from the primary nucleotide sequence of cytochrome oxidase 1 gene (Co-1). Russian Journal of Genetics 46 (3): $356-361$.

Silas, E.G. (1951). Notes on fishes of the genus Glyptothorax Blyth from peninsular India, with description of a new species. Journal of the Bombay Natural History Society 50(2): 367-370.

Steindachner, F. (1867). Ichthyologische Notizen (IV). Sitzungsberichte der Mathematisch-Naturwissenschaftlichen Classe der Kaiserlichen Akademie der Wissenschaften 55(1): 517-534.

Talwar, P.K. \& A.G. Jhingran (1991). Inland Fishes of India and Adjacent Countries. Oxford-IBH Publishing Co. Pvt. Ltd., New Delhi, 1158pp.

Tamura, K., D. Peterson, N. Peterson, G. Stecher, M. Nei \& S. Kumar (2011). MEGA5: Molecular evolutionary genetics analysis using maximum likelihood, evolutionary distance, and maximum parsimony methods. Molecular Biology and Evolution, doi:10.1093/molbev/msr121.

Thomson, A.W. \& L.M. Page (2006). Genera of the Asian catfish families Sisoridae and Erethistidae (Teleostei: Siluriformes). Zootaxa 1345: 1-96.

Thompson, J.D., D.G. Higgins \& T.J. Gibson (1994). CLUSTAL W: improving the sensitivity of progressive multiple sequence alignments through sequence weighting, position specific gap penalties and weight matrix choice. Nucleic Acids Research 22: 4673-4680.

Tilak, R. \& D.N. Tiwari (1976). On the fish fauna of Poona District (Maharashtra). Newsletter Zoological Survey of India 2: 193-199.

Tonapi, G.T. \& L. Mulherkar (1963). Notes on the freshwater fauna of Poona, Part:1, Fishes. Proceedings of the Indian Academy of Sciences 58: 187-197.

Vishwanath, W. \& I. Linthoingambi (2005). A new sisorid catfish of the genus Glyptothorax Blyth from Manipur, India. Journal of the Bombay Natural History Society 102(2): 201-203.

Wagh, G.K \& H.V. Ghate (2003). Freshwater fish fauna of the rivers Mula and Mutha, Pune, Maharashtra. Zoos' Print Journal 18(1): 977-981.

Yadav, B.E. (2003). Ichthyofauna of Northern Part of Western Ghats. Records of the Zoological Survey of India, Occasional Paper No. 215, 40pp.

Yazdani, G.M. \& A. Mahabal (1976). Fishes of Indrayani river. Biovigyanam 2: $119-121$.
Author Detail: Neelesh Dahanukar works in ecology and evolutionary biology with an emphasis on statistical and mathematical analysis. MANAWA DIWEKAR is a molecular biologist with special interests in understanding molecular evolution. MANDAR PAINGANKar is a molecular biologist and works on vector biology with an emphasis on host parasite interactions. He works on animal ecology as a hobby. 